\title{
FAKTOR-FAKTOR PENYEBAB RESIKO JATUH PADA PASIEN DI BANGSAL NEUROLOGI RSUP DR. M DJAMIL PADANG
}

\author{
Julimar \\ STIKes Pekanbaru Medical Center
}

\begin{abstract}
ABSTRAK
The risk of falling is possible for someone to fall which can cause physical injury that is generally caused by environmental and physiological factors that can result in injury. The incidence of the risk of falls that occurred in the Hospital Dr. M Djamil in 2015 as much as 0.5\%. The incidence of the risk of falling in Indonesia in January to September 2012 amounted to 14\%. The high likelihood that a patient runs the risk of falling is influenced by several factors, one of which factors from the patient's own. The purpose of this study to find out what are the factors that greatly affect the safety of patients, especially in the department of neurology ward. Dr. M Djamil Padang. This research was conducted in July-August 2016 for the department. Dr. M Djamil Padang. This research uses descriptive analytical method. The population in this study were nurses who are specifically in the department of Neurology ward. Dr. M Djamil Padang with a sample size of 16 people were taken by total sampling. Data collection tool is a questionnaire. Processing of data by editing, coding, data entry, and tabulating. Analysis of the data used univariate data analysis. The results of this study found that the factors that cause the risk of falls in patients include: more than half (75\%) of respondents rate the organization and management of high factor, more than half (68.75\%) of respondents valued the work environment factors, most of all (94\%) of respondents rated high factor of the team, more than half (75\%) of respondents rated higher personnel factor, less than half (37.5\%) of respondents low duty factor, all (100\%) of respondents rated high patient factors, and more than half (56.25\%) of respondents low rate communication factor. For nurses who value high ratings may be influenced by the style of good leadership in taking any decision, the existence of good cooperation between the heads of the room with the nurse, and their examination environment around the patient. Researchers suggested that nurses still maintain good performance in carrying out its duties and researchers expect that number causes the risk of falling in the neurology ward, especially Hospital Dr. M Djamil Padang reduced.
\end{abstract}

\section{PENDAHULUAN}

Mutu pelayanan yang Keselamatan pasien (Patient Safety) rumah sakit adalah suatu system dimana rumah sakit membuat asuhan pasien lebih aman. Sistem tersebut meliputi assesmen risiko, identifikasi dan pengelolaan hal yang berhubungan dengan risiko pasien, pelaporan dan analisis insiden, kemampuan belajar dari insiden dan tindak lanjutnya serta implementasi solusi untuk meminimalkan timbulnya risiko. System tersebut diharapkan dapat mencegah terjadinya cedera yang disebabkan oleh kesalahan akibat melaksanakan suatu tindakan atau tidak melakukan tindakan yang seharusnya dilakukan (DepKes, 2008).
Pelaporan WHO di Amerika Serikat dalam "To Err Is Human, Buliding a Safer Health System" melaporkan adanya IKP (Insiden keselamatan pasien) dalam pelayanan rawat inap di rumah sakit, kejadian yang terjadi yaitu adanya KTD (Kejadian Tidak Diharapkan) sekitar 3-16\% yang terjadi di rumah sakit Amerika. WHO (World Health Organization) menemukan kasus KTD (Kejadian Tidak Diharapkan) dengan rentang 3,2-16,6\% rumah sakit di berbagai negara, yaitu Amerika, Inggris, Australia, dan Denmark.(Forster et al). Laporan IKP oleh KKP-RS (Komite Keselamatan Pasien-Rumah Sakit) di Indonesia pada bulan Januari-April 2011, menemukan bahwa adanya pelaporan 
kasus KTD (Kejadian Tidak Diharapkan) $(14,41 \%)$ dan KNC (Kejadian Nyaris Cedera) $(18,53 \%)$ yang disebabkan karena proses atau prosedur klinik $(9,26 \%)$, medikasi $(9,26 \%)$, dan Pasien jatuh $(5,15 \%)$. Dalam Kongres Persi XXI di Jakarta pada tanggal 8 November 2014 juga melaporkan bahwa kejadian pasien jatuh di Indonesia pada bulan Januari sampai September 2012 sebesar 14\% 2008).

(DepKes,

Rumah sakit sebagai pemberi layanan kesehatan harus memperhatikan dan menjamin keselamatan pasien. Rumah sakit merupakan organisasi yang berisiko tinggi terhadap terjadinya incident keselamatan pasien yang diakibatkan oleh kesalahan manusia. Kesalahan terhadap keselamatan paling sering disebabkan oleh kesalahan manusia terkait dengan risiko dalam hal keselamatan, dan hal ini disebabkan oleh kegagalan sistem di mana individu tersebut bekerja (Reason, 2009).

Resiko jatuh itu sendiri adalah peningkatan kemungkinan untuk jatuh yang dapat menyebabkan cedera fisik. Resiko jatuh adalah pasien yang berisiko untuk jatuh yang umumnya disebabkan oleh faktor lingkungan dan fisiologis yang dapat berakibat cidera. Kategori resiko jatuh terbagi tiga, yaitu risiko jatuh rendah, risiko jatuh sedang, dan risiko jatuh tinggi (JCI,2011)

Penyebab terjadinya resiko jatuh bisa disebabkan oleh faktor intrinsik berupa riwayat jatuh sebelumnya, penurunan ketajaman penglihatan, prilaku dan sikap berjalan, sistem muskuloskeletal, status mental, penyakit akut, dn penyakit kronik. Dari segi faktor ekstrinsik bisa berupa pengobatan, kamar mandi, desain bangunan, kondisi permukaan lantai, kurang pencahayaan (JCI, 2011).

Akibat yang ditimbulkan dari insiden jatuh dapat menyebabkan kejadian yang tidak diharapkan seperti luka robek, fraktur, cedera kepala, pendarahan sampai kematian, menimbulkan trauma psikologis, memperpanjang waktu perawatan dan meningkatkan biaya perawatan pasien akibat menggunakan peralatan diagnostik yang sebenarnya tidak perlu dilakukan seperti CT Scan, rontgen dll. Dampak bagi rumah sakit sendiri adalah menimbulkan risiko tuntutan hukum karena dianggap lalai dalam perawatan pasien (Miake-Lye dkk, 2013).

Strategi meningkatkan keselamatan pasien oleh Permenkes (2011) melalui enam sasaran keselamatan pasien rumah sakit meliputi identifikasi pasien dengan tepat, meningkatkan komunikasi yang efektif, meningkatkan keamanan obat perlu diwaspadai, memastikan tepat lokasi, tepat prosedur, tepat pasien operasi, mengurangi risiko infeksi terkait pelayanan kesehatan dan mengurangi risiko jatuh. Joint Commision International (JCI) menetapkan sasaran internasional keselamatan pasien dengan meningkatkan keamanan obat-obatan, memastikan lokasi pembedahan, prosedur yang benar dan pembedahan pada pasien yang benar, memastikan keamanan risiko jatuh pasien (JCI, 2011).

Upaya mengantisipasi dan mencegah terjadinya pasien jatuh dengan atau tanpa cidera perlu dilakukan pengkajian di awal maupun kemudian pengkajian ulang secara berkala mengenai resiko pasien jatuh, termasuk resiko potensial yang berhubungan dengan jadwal pemberian obat serta mengambil tindakan untuk mengurangi semua resiko yang telah diidentifikasikan tersebut. Pengkajian resiko jatuh ini telah dapat dilaksanakan sejak pasien mulai mendaftar, yaitu dengan menggunakan skala jatuh. Menghitung MFS (Morse Fall Score) merupakan cara untuk menentukan risiko jatuh dari pasien dan manajemen pencegahan jatuh yang perlu dilakukan sesuai dengan standar prosedur operasional pencegahan jatuh yang telah ada da berlaku diseluruh unit di rumah 
sakit, khususnya di ruang rawat inap (Budiono, 2014)

Ada beberapa faktor yang mempengaruhi terjadinya resiko jatuh yaitu: faktor eksternal, faktor organisasi \& manajemen, faktor lingkungan kerja, faktor tim, faktor petugas, faktor tugas, faktor pasien, dan faktor komunikasi (Kemenkes,2015). Budaya keselamatan merupakan suatu faktor yang menbentuk perilaku profesi kesehatan untuk melihat keselamatan pasien menjadi prioritas utama. Hasil penelitian Helling et al 2008 menyatakan bahwa menilai budaya keselamatan dalam rumah sakit sebagai sebuah tantangan, sehingga diperlukan alat ukur yang akurat dalam penilaiannya. Budaya keselamatan memberikan pengaruh terhadap kualitas pelayanan. Untuk meningktakan budaya keselamatan dibutuhkan dukungan dari manajemen dan seluruh staf. Penelitian diatas bertentangan dengan hasil penelitian yang dilakukan oleh Kartika,2015 yang menunjukkan bahwa tidak ada hubungan yang signifikan antara budaya keselamatan dengan implementasi keselamatan pasien oleh perawat pelaksana. Hal ini dapat terjadi karena dukungan manajemen terhadap keselamatan pasien masih kurang. Hal ini disebabkan karena peningkatan keselamatan pasien belum menjadi misi utama rumah sakit.

Dalam hasil penelitian yang dilakukan Kartika pada tahun 2015 menunjukkan bahwa kerjasama tim tidak berhubungan dengan implementasi keselamatan pasien oleh perawat pelaksana. Hal ini sejalan dengan kenyataan dilapangan bahwa dalam melakukan perawatan kepada pasien, perawat melakukannya hanya kepada pasien yang menjadi tangggung jawabnya dan tugasnya sendiri terhadap pasien sehingga perawat lain tidak saling mengetahui terhadap pekerjaan rekannya. Penelitian ini tidak sejalan dengan penelitian Walshe and Boeden (2006) mengidentifikasi pengaruh kerja tim dengan penampilan kinerja individu yang menyatakan bahwa kerja tim menghasilkan penempilan kinerja individu yang lebih baik pada komunikasi, tugas dan matematis. Hasil penelitian yang dilakukan Kartika juga menunjukkan bahwa ada hubungan kepemimpinan atasan terhadap implementasi keselamatan pasien oleh perawat pelaksana dalam menerapkan patien safety. Penelitian ini didukung oleh Anugrahini (2010) yang menemukan bahwa ada hubungan bermakna antara kepemimpinan atasan langsung dengan implementasi keselamatan pasien.

Dalam hasil penelitian yang dilakukan oleh Suparna tahun 2015 mengatakan perawat dalam memberikan asuhan keperawatan kepada pasien harus menerapkan keselamatan pasien. Perawat harus melibatkan kognitif, afektif, dan tindakan yang mengutamakan keselamatan pasien. Perawat dalam memberikan asuhan keperawatan harus dengan penuh kepedulian. Persepsi perawat untuk menjaga keselamatan pasien sangat berperan dalam pencegahan, pengendalian dan peningkatan keselamatan pasien (Choo, Hutchinson \& Bucknall, 2011; Elley et al, 2008). Pemberi layanan kesehatan berkontribusi terhadap terjadinya kesalahan yang mengancam keselamatan Pasien, Khususnya Perawat, Pelayanan Terlama ( 24 Jam Secara Terus Menerus) dan tersering berinteraksi pada pasien berbagai prosedur dan tindakan keperawatan. Hal ini dapat memberikan peluang yang besar untuk terjadi kesalahan dan keselamatan pasien. Selain itu kelelahan pada perawat merupakan faktor yang berkontribusi terjadinya kesalahan (Mattox, 2012). Karakteristik perawat mempengaruhi pekerjaannya sehari-hari dan berpotensi terhadap kesalahan dalam keselamatan pasien (White, 2012).

Dalam hasil penelitian yang dilakukan Kartika pada tahun 2015 menunjukkan bahwa komunikasi memiliki hubungan yang 
bermakna dengan implementasi keselamatan pasien oleh perawat. Namun, hasil penelitian ini tidak sejalan dengan hasil penelitian Mulyadi (2005) yang menyatakan bahwa tidak terdapat hubungan antara komunikasi dengan kinerja perawat dalam mengendalikan mutu pelayanan keperawatan diruang rawat inap RSKM Cilegon. Hal ini disebabkan karena peneliti berasumsi bahwa keterbukaan dalam komunikasi dapat menurunkan produktifitas kerja.

Berdasarkan observasi dan wawancara yang diakukan peneliti Jelisa Sri Kendiyol seorang mahasiswi keperawatan Universitas Andalas di RSUP Dr. M Djamil dengan Kepala Pengelola Keperawatan Bangsal Neurologi tanggal 15 Maret 2014, didapatkan data bahwa Bangsal Neurologi sudah memiliki laporan kejadian jatuh pasien. Selama tahun 2014 terdapat data laporan 4 kejadian pasien jatuh dan 2 kejadian jatuh di Bangsal Neorologi yang menyebabkan pasien cedera selama bulan Januari-Maret 2014 yang disebabkan oleh ketidakoptimalnya perawat dalam memberikan pelayanan.

Bangsal Neorologi terdiri dari 1 ruang rawat inap dan total jumlah perawat pelaksananya adalah 16 orang (Profil Sumber Daya Manusia Bangsal Neurologi, 2016).

Berdasarkan wawancara tanggal 27 Maret 2016 kepada kepala ruangan di bangsal neurologi didapatkan angka kejadian jatuh selama tahun 2014 sebanyak $0.003 \%$ dan di tahun 2015 sebanyak $0.5 \%$. Mengenai jumlah pasien di ruang rawat inap stroke didapatkan data 22 orang sedang dirawat di ruangan tersebut. Berdasarkan hasil observasi di ruangan pada tanggal 27 Maret 2016, terlihat masing-masing ruangan perawatan sudah memiliki skala pengkajian risiko jatuh Morse yang ditempel di setiap ruang perawat, format pengkajian risiko jatuh pasien sudah tersedia berupa lembaran fotokopi namun belum disatukan dengan status pasien.

\section{METODOLOGI PENELITIAN}

Desain penelitian adalah deskriptif analitik yaitu suatu metode penelitian yang dilakukan dengan tujuan utama mendeskripsikan atau memberi gambaran terhadap suatu obyek penelitian yang diteliti melalui sampel atau data yang telah terkumpul dan membuat kesimpulan yang berlaku umum (Soegiyono, 2009).

Teknik pengambilan sampel adalah (total sampling), yaitu pengambilan sampel yang dilakukan dengan mengambil semua anggota populasi menjadi sampel atau responden. Banyak sampel adalah 16 perawat ( Alimul,2007).

\section{HASIL DAN PEMBAHASAN}

\section{Faktor Organisasi dan Manajemen}

Tabel 1 Distribusi Frekuensi Penyebab Resiko Jatuh Dilihat dari Faktor Organisasi dan Manajemen

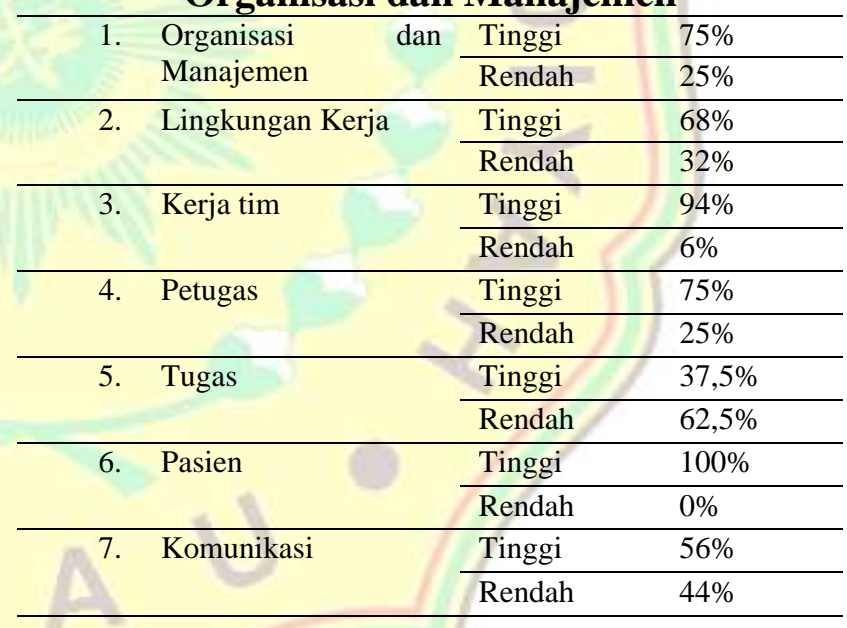

\section{Faktor Organisasi dan Manajemen}

Pada tabel 1 diatas, didapatkan bahwa faktor penyebab resiko jatuh pada pasien lebih dari separuh $(75 \%)$ responden memberikan penilaian yang tinggi pada faktor organisasi dan manajemen. Hasil penelitian ini sama dengan penelitian Kartika (2015) tentang faktor yang berhubungan dengan implementasi keselamatan pasien di Rsud Ajjappannge Soppeng Tahun 2015 dimana lebih dari 
separuh dalam kategori tinggi yaitu $(75,2 \%)$ responden memberikan penilaian mengenai faktor organisasi dan manajemen, hal ini sama dengan hasil yang dilakukan oleh peneliti yaitu dalam kategori tinggi dimana manajemen dan organisasi cukup membantu dalam pengimplementasian tindakan keperawatan terhadap pasien.

Faktor organisasi dan manajemen yaitu kondisi yang ditentukan oleh filosofi dari manajer yang mana akan memotivasi atau gagal memotivasi perawat profesional untuk berpartisipasi pada tingkatan yang konsisten sesuia dengan tujuan (Swansburg, 2010).

Dapat diketahui bahwa tingginya nilai dari faktor organisasi dan manajemen terlihat dari jawaban-jawaban perawat melalui kuisioner yang diberikan, semua (100\%) responden menjawab dalam tiap organisasi memiliki struktur yang hanya dipilih oleh manajer organisasi, semua (100\%) responden menjawab dalam pelaksanaan manajemen resiko jatuh kepala ruangan selalu melakukan pengawasan ke ruang rawat inap dibangsal, semua (100\%) responden menjawab kepala ruangan mengikut sertakan perawat pelaksana untuk mengemukakan pendapat dalam upaya pencegahan resiko jatuh pasien, lebih dari separuh $(75 \%)$ responden menjawab penerapan budaya keselamatan pasien dipengaruhi gaya kepemimpinan yang ada, dan hampir semua responden $(75 \%)$ menjawab kinerja dan cara kerja perawat selalu dipengaruhi tingkat pendidikan yang dimiliki.

\section{Faktor Lingkungan Kerja}

Pada tabel 2 diatas, didapatkan bahwa faktor penyebab resiko jatuh pada pasien lebih dari separuh $(68,75 \%)$ responden memberikan penilaian yang tinggi pada faktor lingkungan kerja. Hasil penelitian ini sama dengan penelitian Budiono, 2014 tentang pelaksanaan program manajemen pasien dengan risiko jatuh di Rumah Sakit Islam Unisma Malang sudah cukup tinggi dimana lebih dari separuh $(73 \%)$ responden memberikan penilaian mengenai faktor lingkungan kerja, hal ini sama dengan hasil yang dilakukan oleh peneliti yaitu dalam kategori tinggi dalam penanganan pasien dengan resiko jatuh.

Dalam jurnal Budiono,2014 faktor lingkungan kerja yaitu suatu keadaan di suatu lingkungan yang diantisipasi dengan cara melakukan ronde lingkungan ditiap-tiap bagian, dimana pada saat ronde lingkungan dilakukan akan ditemukan hal-hal yang mungkin akan menjadi resiko untuk terjadinya jatuh.

Dapat diketahui bahwa tingginya nilai dari faktor lingkungan kerja terlihat dari jawaban-jawaban perawat melalui kuisioner yang diberikan, hampir semua (94\%) responden menjawab dalam pemindahan pasien keruangan rawat inap lain ditemukan hal-hal yang mungkin menjadi resiko untuk terjadinya jatuh, semua (100\%) responden menjawab perawat pelaksana selalu melakukan pemeriksaan disekitar lingkungan pasien yang beresiko jatuh, lebih dari separuh $(63 \%)$ responden menjawab dalam penggunaan alat elektronik, terjadi malfungsi peralatan yang digunakan, separuh (50\%) responden menjawab sering terjadi kekurangan peralatan medis saat melakukan suatu tindakan, dan semua $(100 \%)$ responden menjawab peralatan yang selesai digunakan selalu diberikan desinfektan agar tidak menimbulkan infeksi nosokomial.

\section{Faktor Tim}

Pada tabel 3 diatas, didapatkan bahwa faktor penyebab resiko jatuh pada pasien hampir dari semua $(94 \%)$ responden memberikan penilaian yang tinggi pada faktor tim. Hasil penelitian ini sama dengan penelitian Kartika (2015) tentang faktor yang berhubungan dengan implementasi keselamatan pasien di Rsud Ajjappannge 
Soppeng Tahun 2015 dimana hampir semua $(88,3 \%)$ responden memberikan penilaian yang tinggi mengenai faktor tim, hal ini sama dengan hasil yang dilakukan oleh peneliti yaitu dalam kategori tinggi dimana kerja sama tim cukup membantu dalam pengimplementasian tindakan keperawatan terhadap pasien.

Faktor tim yaitu faktor yang dipengaruhi baik dari segi kepemimpinan dan tanggung jawab dimana kepala ruangan memiliki peran dalam mendukung budaya keselamatan pasien dan menciptakan lingkungan yang positif bagi keselamatan pasien (Yaqin et al,2012).

Dapat diketahui bahwa tingginya nilai dari faktor tim yang mempengaruhi terjadinya resiko jatuh pada pasien terlihat dari jawabanjawaban perawat melalui kuisioner yang diberikan, hampir semua (94\%) responden menjawab dalam melakukan tindakan perawat yang baru bekerja selalu meminta pemberian arahan dari perawat pelaksana yang memiliki pengalaman lebih banyak, hampir semua (81 $\%)$ responden menjawab perawat diruangan selalu bersifat cepat tanggap dalam menangani pasien dengan resiko jatuh, lebih dari separuh $(56,25 \%)$ responden menjawab pemberian tindakan keperawatan dibedakan sesuai tingkat pendidikan yang dimiliki oleh perawat, hampir semua $(88 \%)$ responden menjawab kepala ruangan memiliki peran yang kritis dalam penentu pengambilan tindakan penanganan pasien dengan resiko jatuh, dan semua (100\%) responden menjawab kepala ruangan mampu melakukan pembagian kerja sesuai kemampuan yang dimiliki oleh masing-masing perawat.

\section{Faktor Petugas}

Pada tabel 4 diatas, didapatkan bahwa faktor penyebab resiko jatuh pada pasien lebih dari separuh $(75 \%)$ responden memberikan penilaian yang tinggi pada faktor petugas. Hasil penelitian ini sama dengan penelitian
Budiono, 2014 tentang pelaksanaan program manajemen pasien dengan risiko jatuh di Rumah Sakit Islam Unisma Malang sudah cukup tinggi dimana hampir dari semua (87\%) responden memberikan penilaian mengenai faktor petugas, hal ini sama dengan hasil yang dilakukan oleh peneliti yaitu dalam kategori tinggi dalam penanganan pasien dengan resiko jatuh.

Faktor petugas yaitu faktor yang disebabkan adanya persaingan dalam kompetensi antar perawat dimana pengetahuan berperan penting dan berhubungan dengan komitmen yang sangat diperlukan dalam upaya membangun budaya keselamatan pasien (Notoatmodjo,2007).

Dapat diketahui bahwa tingginya nilai dari faktor petugas terlihat dari jawabanjawaban perawat melalui kuisioner yang diberikan, hampir semua $(88 \%)$ responden menjawab setiap perawat pelaksana harus mengikuti pelatihan dan memiliki verifikasi dalam menangani pasien dengan resiko jatuh, semua (100\%) responden menjawab tingkat pengetahuan dan keterampilan kerja perawat berpengaruh dalam penanganan pasien dengan resiko jatuh, semua (100\%) responden menjawab motivasi berpengaruh dalam meningkatkan kinerja seorang perawat, lebih dari separuh (75\%) responden menjawab bebean kerja yang terlalu tinggi selalu mempengaruhi produktivitas kerja perawat dalam melakukan suatu tindakan, dan lebih dari separuh (63\%) responden menjawab kebanyakan perawat memiliki gangguan pada fisiknya akibat dari efek beban kerja yang terlalu berlebihan.

\section{Faktor Tugas}

Pada tabel 5 diatas, didapatkan bahwa faktor penyebab resiko jatuh pada pasien kurang dari separuh $(37,5 \%)$ responden memberikan penilaian yang rendah pada faktor tugas. Hasil penelitian ini tidak sama dengan 
Setyarini,2013 dalam kepatuhan perawat melaksanakan standar prosedur operasional: pencegahan pasien resiko jatuh di gedung yosef 3 dago dan surya kencana rumah sakit borromeus dimana lebih dari separuh $(75 \%)$ responden meberikan penilaian yang tinggi dalam kepatuhan perawat melaksanakan tindakan keperawatan sesuai standar prosedur operasional pencegahan pasien resiko jatuh, sedangkan hasil yag didapatkan peneliti tugas dari petugas kesehatan cukup rendah dalam pelaksanaan tindakan keperawatan.

Dalam jurnal Setrayini,2013 faktor tugas yaitu faktor yang dipengaruhi baik dari segi ketersediaan SOP dimana dengan adanya SOP sebagai acuan kerja mampu menghasilkan sumber daya manusia yang profesional.

Dapat diketahui bahwa rendahnya nilai dari faktor tugas terlihat dari jawaban-jawaban perawat melalui kuisioner yang diberikan, semua (100\%) responden menjawab dalam melakukan tindakan perawat selalu mengikuti produser sesuai SOP, semua (100\%) responden menjawab perawat selalu melakukan pencegahan resiko jatuh sesuai standar SPO yang sudah ditetapkan, separuh (50\%) responden menjawab saat dilakukan pemeriksaan didapatkan ketidaksesuaian antara interpretasi hasil test, kurang dari separuh $(38 \%)$ responden menjawab sebagian besar pasien dengan resiko jatuh tidak menjalani pemeriksaan atau pengkajian dengan skala MFS (Morse Fall Score), dan kurang dari separuh (38\%) responden menjawab untuk pasien dengan resiko jatuh hanya dilakukan pengkajian melalui MFS tanpa dilakukan pemasangan gelang identifikasi pasien resiko jatuh oleh perawat pelaksana.

\section{Faktor Pasien}

Pada tabel 6 diatas, didapatkan bahwa faktor penyebab resiko jatuh pada pasien semua $(100 \%)$ responden memberikan penilaian yang tinggi pada faktor pasien. Hasil penelitian ini sama dengan penelitian Budiono, 2014 tentang pelaksanaan program manajemen pasien dengan risiko jatuh di Rumah Sakit Islam Unisma Malang sudah cukup tinggi dimana hampir dari separuh $(80 \%)$ responden memberikan penilaian mengenai faktor pasien, hal ini sama dengan hasil yang dilakukan oleh peneliti yaitu dalam kategori tinggi dalam penanganan pasien dengan resiko jatuh.

Dalam jurnal Budiono,2014 faktor pasien yaitu faktor yang dapat dilihat baik dari segi kondisi dimana ganguan mobilitas menjadi salah satu penyebab utama seseorang beresiko untuk jatuh.

Dapat diketahui bahwa tingginya nilai dari faktor pasien terlihat dari jawabanjawaban perawat melalui kuisioner yang diberikan, semua (100\%) responden menjawab penyebab utama seorang pasien memiliki resiko jatuh adalah gangguan mobilitas pada tubuh pasien, hampir semua (94\%) responden menjawab penyebab utama resiko jatuh pasien adalah karena ketidakterlibatang keluarga dalam merawat dan menjaga pasien, lebih dari separuh $(75 \%)$ responden menjawab obatobatan yang dikonsumsi pasien seringkali menjadi penyebab seorang pasien memiliki resiko jatuh, hampir semua $(81 \%)$ responden menjawab adanya riwayat jatuh sebelumnya selalu menimbulkan trauma pada pasien dengan resiko jatuh, dan semua (100\%) responden menjawab hubungan yang baik antara perawat dengan pasien mampu mengurangi resiko jatuh.

\section{Faktor Komunikasi}

Pada tabel 7 diatas, didapatkan bahwa faktor penyebab resiko jatuh pada pasien lebih dari separuh $(56,25 \%)$ responden memberikan penilaian yang rendah pada faktor komunikasi. Hasil penelitian ini tidak sama dengan penelitian Kartika (2015) tentang faktor yang 
berhubungan dengan implementasi keselamatan pasien di Rsud Ajjappannge Soppeng Tahun 2015 dimana lebih dari separuh $(67,1 \%)$ responden memberikan penilaian cukup tinggi mengenai faktor komunikasi, hal ini tidak sama dengan hasil yang dilakukan oleh peneliti yaitu dalam kategori rendah dalam penanganan pasien dengan resiko jatuh.

Dalam jurnal Kartika,2015 faktor komunikasi yaitu suatu bentuk komunikasi yang dapat dilihat baik secara verbal maupun secara tulisan dimana/komunikasi sangat berpengaruh dalam pencegahan resiko jatuh pasien, dimana buruknya komunikasi antar dokter dan perawat menjadi salah satu penyebab terjadinya kejadian yang tidak diharapkan, komunikasi yang tidak terdokumentasikan dengan baik juga dapat menimbulkan kesalahan.

Dapat diketahui bahwa rendahnya nilai dari faktor komunikasi terlihat dari jawabanjawaban perawat melalui kuisioner yang diberikan, lebih dari separuh $(63 \%)$ responden menjawab sering terjadi salah penyampaian informasi dalam pergantian jam dinas antar perawat akibat cara penyampaian yang tidak jelas, hampir dari separuh $(81 \%)$ responden menjawab kurangnya penyampaian informasi hanya boleh dilakukan oleh perawat yang telah lama bekerja di ruangan, lebih dari separuh (63\%) responden menjawab komunikasi yang digunakan perawat dalam berkomunikasi dipengaruhi oleh tingkat pendidikan perawat , semua responden $(100 \%)$ menjawab komunikasi terapeutik wajib diterapkan saat perawat berkomunikasi dengan pasien, dan separuh $(50 \%)$ responden menjawab seringkali terjadi ketidaklengkapan informasi saat didokumentasikan oleh perawat dalam bentuk tertulis.

\section{KESIMPULAN}

1 Lebih dari separuh $(75 \%)$ responden memiliki nilai yang tinggi dalam menilai faktor organisasi dan manajemen

2 Lebih dari separuh $(68,75 \%)$ responden memiliki nilai yang tinggi dalam menilai faktor lingkungan kerja .

3 Hampir dari semua (94\%) responden memiliki nilai yang tinggi dalam menilai faktor tim

4 Lebih dari separuh (75\%) responden memiliki nilai yang tinggi dalam menilai faktor petugas.

5 Kurang dari separuh $(37,5 \%)$ responden memiliki nilai yang rendah dalam menilai faktor tugas.

6 Semua (100\%) responden memiliki nilai yang tinggi dalam menilai faktor pasien.

7 Lebih dari separuh $(56,25 \%)$ responden memiliki nilai yang rendah dalam menilai faktor komunikasi.

\section{Saran}

Diharapkan bagi pihak perawat pelaksana di rumah sakit dapat menggunakan hasil penelititan ini menjadi bahan masukan dan dapat meningkatkan kinerja dalam memberikan pelayanan kesehatan yang lebih baik dan berkualitas bagi pasien. Dilihat dari baiknya respon perawat terhadap beberapa faktor yang dapat menjadi penyebab resiko jatuh pada pasien. Dari faktor lingkungan kerja perawat selalu melakukan ronde lingkungan disekitar lingkungan pasien yang memiiki resiko jatuh. Faktor tim juga dapat menjadi penyebab resiko jatuh, dilihat dari peran kritis dan ada tidaknya kerja sama antar sesama perawat pelaksana dan kepala ruangan.

\section{DAFTAR PUSTAKA}

Adib A. 2009. Materi Seminar Nasional Keperawatan dengan tema "Sistem Pelayanan Keperawatan dan Manajemen Rumah Sakit untuk 
Mewujudkan Patient Safety”. Jogjakarta

JCI, 2011. Joint Commission International Acreditation Standards for Hospital.

Arikunto, Suharsimi, 2013. Prosedur 4th Edition

Penelitian Suatu Pendekatan Praktek. Jakarta : Rineka Cipta

KKP-RS,2008. Panduan Nasional Keselamatan Pasien Rumah Sakit.

Astrianti, 2014. Gambaran Determinan Insiden Keselamatan Pasien Pada Petugas Kesehatan Di Rumah Sakit Universitas Hasanuddin [Skripsi]. Makassar : Universitas Hasanuddin

Budiono, Sugeng, Arief Alamsyah dan Wahyu, 2014. Pelaksanaan Program Manajemen Pasien dengan Rsiko Jatuh di Ruma Sakit. Jurnal Kedokteran Brawijaya, vol.28. Suplemen No.1

Departemen Kesehatan R.I, 2008. Panduan Nasional Keselamatan Pasien Rumah Sakit. Jakarta : Bhakti Husada

RSUP DR M Djamil Padang ,2015 Data laporan Tahunan.

WHO,2009. Human Factors in Patient Safety Review of Topics and Tools. [Online Journal], Jakarta,World Healt Organization 